\title{
Bioprospection of Trichoderma spp. originating from a Cerrado-Caatinga ecotone on Colletotrichum truncatum, in soybean
}

\author{
Helane França Silva ${ }^{1} \oplus$, Alice Maria Gonçalves Santos ${ }^{1} \oplus$, Ana Cláudia Tenório do Amaral ${ }^{2} \oplus$, \\ José Luiz Bezerra ${ }^{3}$, Edna Dora Martins Newman Luz ${ }^{4}$

\footnotetext{
2 Universidade Federal de Pernambuco, Recife-PE, Brasil. E-mail: ana-claudia52@hotmail.com

${ }^{3}$ Universidade Federal do Recôncavo da Bahia, Cruz das Almas-BA, Brasil. E-mail: jlulabezerra@hotmail.com
} \\ 1 Universidade Federal do Piauí, Bom Jesus-PI, Brasil. E-mail: helane.engflo@gmail.com; alicemgsantos@yahoo.com.br \\ ${ }^{4}$ Comissão Executiva do Plano da Lavoura Cacaueira, Brasília-DF, Brasil. E-mail: ednadora@yahoo.com.br
}

ABSTRACT: This study aimed to assess the potential of 19 isolates of Trichoderma spp. originating from a Cerrado-Caatinga ecotone in control of Colletotrichum truncatum, in soybean. In vitro tests (inhibitory effect of volatile and fixed thermostable metabolites) were carried out to assess the percentage of mycelial growth of the pathogen and in vivo tests (in soybean seeds) were performed to assess the percentage of germination, germination rate index, dry matter, and health of seeds. Regarding the pathogen growth under the effect of volatile and fixed thermostable metabolites, the lowest values were provided, respectively, by the isolates UFPIT03 (49.25\%) and UFPIT13 (38.38\%). No significant differences were observed in the in vivo tests regarding the action of volatile metabolites of the different isolates. In relation to the effect of fixed metabolites, the isolates UFPIT11 and UFPIT19 presented the best results, with the highest means of seed dry matter and lower pathogen incidence. However, the other isolates also showed positive results. It is noteworthy that this is the first report of Trichoderma orientale in the biocontrol of a plant pathogen. Thus, the perspectives of using these species of Trichoderma originating from native forest fragments in the biological control of phytopathogens are evidenced.

Key words: antagonism; anthracnose; biological control; plant protection

\section{Bioprospecção de Trichoderma spp. originadas de um ecótono Cerrado-Caatinga sobre Colletotrichum truncatum, em soja}

RESUMO: Objetivou-se com o presente trabalho avaliar o potencial de 19 isolados de Trichoderma spp. originárias de um ecótono Cerrado-Caatinga no controle de Colletotrichum truncatum, em soja. Foram realizados testes in vitro (efeito inibitório de metabólitos voláteis e fixos termoestáveis), em que se avaliou a porcentagem de crescimento micelial do patógeno e testes in vivo (em sementes de soja), sendo avaliados a porcentagem de germinação, o índice de velocidade de germinação, a massa seca e a sanidade das sementes. Em relação ao crescimento do patógeno, sob efeito de metabólitos voláteis e fixos termoestáveis, os menores valores foram proporcionados, respectivamente, pelos isolados UFPIT03 (49,25\%) e UFPIT13 $(38,38 \%)$. Nos testes in vivo, não foram observadas diferenças significativas quanto a ação de metabólitos voláteis dos diferentes isolados. Em se tratando do efeito de metabólitos fixos, os isolados UFPIT11 e UFPIT19 apresentaram os melhores resultados, proporcionando as maiores médias de massa seca da semente e menor incidência do patógeno. Contudo, os demais isolados também apresentaram resultados positivos. Vale ressaltar que este é o primeiro relato de Trichoderma orientale no biocontrole de um fitopatógeno. Assim, evidencia-se as perspectivas do uso dessas espécies de Trichoderma originárias de fragmentos florestais nativos, no controle biológico de fitopatógenos.

Palavras-chave: antagonismo; antracnose; controle biológico; proteção de plantas 


\section{Introduction}

The Southwest of Piauí, one of the four mesoregions of the state, is considered one of the last agricultural frontiers of Brazil. This mesoregion is mainly located in areas of the Cerrado biome, also encompassing areas of the Caatinga biome, as well as ecotone areas of these two biomes (Botrel et al., 2015). The Cerrado-Caatinga ecotone region consists of the third largest transitional area of Brazil, extending through regions of the states of Piauí, Bahia, and Minas Gerais. Despite its importance, especially in relation to biological diversity, studies in these areas are scarce.

Baldoni (2014) pointed out that in addition to biodiversity there is the contribution of ecotone zones as centers of endemism, thus evidencing the importance of research in these areas to support strategies for conservation and management of their biodiversity. In addition, it is worth noting that in a scenario of growing interest of the biotechnology industry by the use of microorganisms and plants as biofactories of substances for various purposes (Costa, 2011), ecotone areas can work as reservoirs of biofactories of potential microorganisms, for instance, for use in the biological control of plant diseases.

The use of biocontrol in disease management in several countries is still a little-adopted practice when compared to the use of pesticides. DiTomaso et al. (2017), attribute this deficiency to regulatory and political aspects that hinder the practice of biological control in many countries, including the United States, where agriculture is highly developed. In Brazil, the increasing exports of food products have contributed to the need for reducing chemical residues in products and, consequently, given a higher incentive for the adoption of biological control (Parra, 2014). In addition, considering the significant production losses due to the attack of pathogens of varied etiologies, especially fungi, the use of antagonists stands out as a viable alternative to the use of chemical fungicides.

Among the pathogens of great relevance in the Southwest of Piaui due to the damage caused especially to soybean, Glycine max (L.) Merrill - Fabaceae, the main crop produced in the state, the fungus Colletotrichum truncatum Schwein Andrus and Moore stands out since it causes a disease known as anthracnose. This pathogen has a wide range of hosts and infected seeds are one of the main initial sources of inoculum (Manandhar \& Hartman, 1999). In soybean, anthracnose causes rot and fall of leaves and pods (Galli et al., 2005), in addition to reducing seed germination and seedling survival, as well as its lodging (Begum et al., 2008). In this sense, Barratt et al. (2018) emphasize the need for and importance of researches related to the biological control aiming to discover the potential of biocontrol agents and the cost-benefit of its implementation to support the use and wider diffusion of this practice worldwide.

Among the antagonistic microorganisms used in biological control, the fungi of the genus Trichoderma stand out. They can act mainly by competition, in which antagonist and pathogen compete for nutrients and/or space or antibiosis when the antagonist secretes metabolites harmful to pathogens. Bhardwaj \& Kumar (2017) reported that the production of volatile or fixed antifungal compounds varies between different Trichoderma isolates, with effective and potential metabolites that can be exploited in the management of plant diseases.

Species of the genus Trichoderma may also act by parasitism, in which the biocontrol agent infects the pathogen. According to Grigoletti Junior et al. (2000), parasitism is one of the most efficient mechanisms of natural biological control since the antagonist needs the same conditions of the pathogen to survive. Thus, bioagents collected in the same environment or under climatic conditions similar to those where they will be used are more likely to adapt and be more effective. Therefore, it is of great relevance to study the action of Trichoderma spp. isolated from native areas, considering its relevant antagonistic potential against phytopathogens.

In this context, this study was carried out with the objective of assessing the antagonistic action of Trichoderma spp. originating from a Cerrado-Caatinga ecotone on $C$. truncatum in soybean, in the state of Piauí, Brazil.

\section{Materials and Methods}

\section{Origin of the isolates of Trichoderma spp.}

Nineteen isolates of Trichoderma spp. originating from leaves of forest species located in a Cerrado-Caatinga transition area, located at the geographical coordinates $8^{\circ} 51^{\prime} 7.48^{\prime \prime} S$ and $44^{\circ} 11^{\prime} 39.95^{\prime \prime} \mathrm{W}$, were used in this study. This area consists of a legal reserve of $1,049.76$ ha, from which a 1.0 ha fragment was used to obtain the isolates.

For the identification of the Trichoderma isolates (Table 1), the DNA regions studied were the translation elongation fator tef1 and the second largest RNA polymerase subunit ( $r p b 2)$.

Table 1. Identification of the isolates of Trichoderma spp. obtained from leaves of forest species in the Cerrado-Caatinga transition área, in Piauí, Brazil.

\begin{tabular}{|c|c|}
\hline Isolates & Species \\
\hline UFPIT01 & T. orientale \\
\hline UFPIT02 & T. longibrachiatum \\
\hline UFPIT03 & T. koningiopsis \\
\hline UFPIT04 & Trichoderma sp. T1 \\
\hline UFPIT05 & Trichoderma sp. T2 \\
\hline UFPIT06 & Trichoderma sp. T3 \\
\hline UFPIT07 & T. koningiopsis \\
\hline UFPIT08 & Trichoderma sp. T4 \\
\hline UFPIT09 & T. orientale \\
\hline UFPIT10 & T. koningiopsis \\
\hline UFPIT11 & Trichoderma sp. T5 \\
\hline UFPIT12 & T. orientale \\
\hline UFPIT13 & Trichoderma sp. T6 \\
\hline UFPIT14 & T. orientale \\
\hline UFPIT15 & T. orientale \\
\hline UFPIT16 & T. koningiopsis \\
\hline UFPIT17 & T. orientale \\
\hline UFPIT18 & T. orientale \\
\hline UFPIT19 & T. koningiopsis \\
\hline
\end{tabular}


Inhibitory effect of volatile and fixed thermostable metabolites of Trichoderma spp. on Colletotrichum truncatum

The pathogen $C$. truncatum was obtained from infected soybean pods in areas of the same mesoregion where the isolates of Trichoderma spp. were found. The infected plant material was cultivated in Petri dishes in a Potato-DextroseAgar (PDA) medium, incubated at $25^{\circ} \mathrm{C}$ and 12-hour photoperiod, to isolate the phytopathogen.

To verify the in vitro inhibitory effect of volatile metabolites, Petri dishes containing PDA medium received discs from $C$. truncatum and other cultures, isolated from Trichoderma spp. After $24 \mathrm{~h}$, the bases of the dishes containing the pathogen and antagonist were overlapped and bound with a clear plastic film (Dennis \& Webster, 1971). The dishes were incubated at $25{ }^{\circ} \mathrm{C}$ and 12-hour photoperiod so that the pathogen was superimposed on the antagonist. As a control, the dishes with pathogen were superimposed on dishes containing only PDA medium. Each treatment was composed of four replications in a completely randomized design. The growth in diameter of colonies was assessed daily from 24 hours after experiment setup, during seven days. The final area occupied by the control was considered as $100 \%$ growth to obtain the means of pathogen growth.

To assess the inhibitory effect of thermostable fixed metabolites, five discs $(5 \mathrm{~mm})$ of agar extracted from the margins of cultures of the isolates of Trichoderma spp. were transferred to Erlenmeyer flasks $(250 \mathrm{~mL}$ ) containing $100 \mathrm{~mL}$ of potato-dextrose (PD) medium. After six days of cultivation under agitation at $120 \mathrm{rpm}$, without the presence of light and temperature of $25{ }^{\circ} \mathrm{C}$, culture filtrates from the antagonists were obtained using sterile gauze, being autoclaved at $120^{\circ} \mathrm{C}$ for 20 minutes (Guimarães et al., 2016). Subsequently, $5 \mathrm{~mL}$ of the filtrate from each isolate was added to $15 \mathrm{~mL}$ of molten PDA in Petri dishes. The control consisted of adding $5 \mathrm{~mL}$ of sterile PD medium (without antagonist) to the molten PDA. After solidification, a $5 \mathrm{~mm}$ disc containing pathogen mycelium was deposited on the medium surface (Agrawal et al., 1977). The dishes were incubated at $25^{\circ} \mathrm{C}$ and 12 -hour photoperiod for seven days. During this period, the diameters of pathogen colonies were measured. Each treatment consisted of four replications in a completely randomized design. The final area occupied by the control was also considered as $100 \%$ growth to obtain the means of pathogen growth.

Inhibitory action of Trichoderma spp. to Colletotrichum truncatum in soybean seeds

From the results obtained in vitro, isolates of Trichoderma spp. were selected for in vivo tests in soybean seeds. Ten isolates were selected for the assessment of volatile metabolites and nine isolates were tested for fixed metabolites. The experiments were conducted in a completely randomized design with eight replications of 25 seeds.

In order to perform both tests, soybean seeds of the cultivar 8808 IPRO Monsoy ${ }^{\circledR}$, with moderately resistant characteristics to Corynespora cassiicola (Berk. \& M. A. Curtis)
C. T. Wei (Monsoy, 2018), but susceptible to C. truncatum. Seeds were disinfected in $1 \%$ sodium hypochlorite solution for two minutes, washed in sterilized water, and dried at ambient temperature. The inoculation of $C$. truncatum was carried out by conidia suspension. Soybean seeds were immersed in the suspension with concentration adjusted to $10^{5}$ conidia $\mathrm{mL}^{-1}$ for five minutes. Each $40 \mathrm{~g}$ of seeds received $10 \mathrm{~mL}$ of this suspension. These seeds were then placed in a plastic tray containing as substrate two sheets of sterilized germitest paper and moistened in PDA medium (HIMEDIA ${ }^{\circledR}$ ) plus the solute mannitol (VETEC ${ }^{\circledR}$ ) with an osmotic potential adjusted to -1.0 Mpa, according to the software SPMM (Michel \& Radcliffe, 1995). After 48 hours of incubation in BOD at $20^{\circ} \mathrm{C}$, the inoculated seeds were used to carry out the tests of pathogen inhibition by the action of volatile and fixed metabolites of Trichoderma spp.

The double-plate system was used to assess the effect of volatile metabolites of Trichoderma spp. on soybean seeds inoculated with $C$. truncatum (Lee et al., 2015). A small Petri dish $(60 \times 15 \mathrm{~mm})$ containing the isolates of antagonists grown in PDA was placed in a large Petri dish $(150 \times 30 \mathrm{~mm})$ containing inoculated soybean seeds. Seeds and isolates were grown together at $25{ }^{\circ} \mathrm{C}$ and 12 -hour photoperiod for eight days. Seeds inoculated with the pathogen were used as a control, without the presence of Trichoderma spp.

For the tests with fixed metabolites, seeds previously inoculated (48 h) with $C$. truncatum were immersed for one minute in a suspension of each of the isolates of Trichoderma spp. with $10^{8}$ conidia $\mathrm{mL}^{-1}$ for each $100 \mathrm{~g}$ of seeds. Seeds inoculated with $C$. truncatum were used as a control, without the presence of Trichoderma spp. In order to compare the antagonistic potential of these isolates of Trichoderma spp., the commercial product Quality ${ }^{\circledR}$, based on T. asperellum (isolate SF 04, with a minimum concentration of $1 \times 1010 \mathrm{CFU}$ $\mathrm{g}^{-1}$ ), was used in the proportion of $1 \mathrm{~g} \mathrm{~kg}^{-1}$ of seeds, according to the manufacturer's recommendation.

Germination, vigor and health of soybean seeds treated with Trichoderma spp.

Assessments of germination, vigor, and health of seeds were carried out at eight days after experiment setup. The assessment of germinated seeds was performed daily from the radicle protrusion. After obtaining the daily data, the germination rate index (GRI) was calculated using the equation proposed by Maguire (1962): $\mathrm{GRI}=\mathrm{G} 1 / \mathrm{N} 1+\mathrm{G} 2 / \mathrm{N} 2+\ldots$ $+\mathrm{Gn} / \mathrm{Nn}$, where $\mathrm{G}$ is the number of normal seedlings observed at each count and $\mathrm{N}$ is the number of days from sowing to the respective counts. The incidence of $C$. truncatum in the seeds was assessed with stereoscopic and optical microscopes, in which the presence or absence of the pathogen was verified in each seed and the results were expressed as the percentage of pathogen incidence.

Subsequently, the seedlings were conditioned in paper bags and dried in an oven at $60{ }^{\circ} \mathrm{C}$ until constant weight to determine the dry matter. The weighing was performed on a precision scale and the data expressed in grams. 


\section{Statistical analysis}

The data obtained from the in vitro and in vivo tests were submitted to analysis of variance and the effects of treatments were compared by the Tukey's test at $5 \%$ probability using the software SISVAR 5.6 (Ferreira, 2015).

\section{Results and Discussion}

Action of volatile and fixed thermostable metabolites of Trichoderma spp. on Colletotrichum truncatum

The percentage of growth of $C$. truncatum varied from $49.25 \%$ (UFPITO3) to $99.24 \%$ (UFPITO2) in relation to the control under the effect of volatile metabolites of Trichoderma spp. (Table 2). However, the lower growth rate of the isolate UFPIT03 differed only from the isolates UFPIT02 and UFPIT14. In addition, the isolates UFPIT03, UFPIT05, UFPIT07, UFPIT09, UFPIT10, UFPIT13 and UFPIT18 stopped the growth of $C$. truncatum on the second day after incubation and it may be related to a high release of volatile metabolites by these isolates.

The volatile metabolites produced by Trichoderma spp. include compounds such as pyrone (Claydon et al., 1987), anthraquinone, butenolide (Almassi et al., 1991), cyclopentyl isocyanate, isonitrine-type compounds, and peptaibols (Claydon et al., 1987; Hlimi et al., 1995). They were reported

Table 2. Inhibitory effect of volatile and fixed thermostable metabolites of Trichoderma spp. on the growth of Colletotrichum truncatum at the end of seven days. Means with the same letter in the column do not differ from each other by the Tukey's test at $5 \%$ probability $(p \geq 0.05)$.

\begin{tabular}{|c|c|c|}
\hline \multirow{2}{*}{$\begin{array}{c}\text { Isolate } \\
\text { of Trichoderma spp. }\end{array}$} & \multicolumn{2}{|c|}{$\begin{array}{l}\text { Growth (\%) of } C \text {. truncatum colonies } \\
\text { under the effect of Trichoderma spp. }\end{array}$} \\
\hline & $\begin{array}{l}\text { Volatile } \\
\text { metabolite }\end{array}$ & $\begin{array}{c}\text { Fixed } \\
\text { thermostable } \\
\text { metabolite }\end{array}$ \\
\hline UFPIT01 & $92.58 \mathrm{abcd}$ & $97.84 a$ \\
\hline UFPIT02 & 99.24 abc & $99.53 \mathrm{a}$ \\
\hline UFPIT03 & $49.25 d$ & $99.83 a$ \\
\hline UFPITO4 & $59.43 \mathrm{bcd}$ & 99.87 a \\
\hline UFPIT05 & $54.14 \mathrm{bcd}$ & $97.36 \mathrm{a}$ \\
\hline UFPIT06 & $70.09 \mathrm{abcd}$ & $72.56 \mathrm{abc}$ \\
\hline UFPIT07 & $60.21 \mathrm{abcd}$ & $98.96 \mathrm{a}$ \\
\hline UFPIT08 & $84.71 \mathrm{abcd}$ & $52.33 \mathrm{~cd}$ \\
\hline UFPIT09 & $56.61 \mathrm{bcd}$ & $99.29 \mathrm{a}$ \\
\hline UFPIT10 & $53.64 \mathrm{bcd}$ & 99.81 a \\
\hline UFPIT11 & $80.34 \mathrm{abcd}$ & $98.45 \mathrm{a}$ \\
\hline UFPIT12 & $90.14 \mathrm{abcd}$ & $80.69 a b$ \\
\hline UFPIT13 & $63.86 \mathrm{abcd}$ & $38.38 \mathrm{~d}$ \\
\hline UFPIT14 & $96.15 a b c$ & $47.51 \mathrm{~cd}$ \\
\hline UFPIT15 & $85.03 \mathrm{abcd}$ & $97.75 \mathrm{a}$ \\
\hline UFPIT16 & $61.57 \mathrm{abcd}$ & $52.98 \mathrm{~cd}$ \\
\hline UFPIT17 & $62.70 \mathrm{abcd}$ & $99.40 \mathrm{a}$ \\
\hline UFPIT18 & $50.65 \mathrm{~cd}$ & $97.98 \mathrm{a}$ \\
\hline UFPIT19 & $88.03 \mathrm{abcd}$ & $94.12 \mathrm{a}$ \\
\hline Control & $100.00 \mathrm{a}$ & $100.00 \mathrm{a}$ \\
\hline $\begin{array}{l}\text { Coefficient of } \\
\text { variation (\%) }\end{array}$ & 23.49 & 12.50 \\
\hline
\end{tabular}

to play an important role in the management of plant pathogens such as Gaeumannomyces graminis var. tritici J. Walker (Ghisalberti et al., 1990), Rhizoctonia solani J.G. Kühn and Fusarium oxysporum f. sp. lycopersici (Sacc.) W.C. Snyder \& H.N. Hans (Scarselletti \& Faull, 1994), and Phytophthora spp. (Reino et al., 2008). Thus, it is worth emphasizing the importance of identifying metabolites produced by these isolates of Trichoderma spp., which showed better responses regarding the antagonism for future use in studies aimed at the biocontrol of other pathogens, as well as for prospecting the production of metabolites of agroindustrial interest.

The growth of the pathogen under the effect of fixed thermostable metabolites started from the second day of incubation in all treatments, which may be due to the release of these compounds in the first hours. A variation of pathogen growth between $38.38 \%$ (UFPIT13) and $99.87 \%$ (UFPIT04) was observed (Table 2).

The isolates UFPIT08, UFPIT13, UFPIT14 and UFPIT16 provided the highest inhibition effects, not statistically differing from each other. The greater inhibition action presented by these isolates when compared to the others may be related to the thermostability of the metabolites produced by them. In tests for the thermostability of metabolites produced by Trichoderma spp., Isaías et al. (2014) found that although the reduction in the percentages of inhibition, the metabolites of Trichoderma spp. remained active even after autoclaving because they inhibited the mycelial growth of pathogens, indicating the potential of these antifungal metabolites under the used experimental conditions.

On the other hand, Smith (2014) observed that bioactive molecules in microorganism metabolites could be decomposed into other less active or even inactive molecules when submitted to inappropriate conditions such as high temperatures. This evidence may lead to the hypothesis that the low efficiency in the antagonistic action presented by some isolates may be related to a reduction of the activity of metabolites produced by antagonists when submitted to high temperatures.

Several factors must be analyzed for the choice of an isolate for its field application. The fact that metabolites produced by some isolates of Trichoderma spp. showed to be stable at high temperatures allow us to deduce that they can remain active against different factors, such as insolation and higher soil temperatures of different regions (Guimarães et al., 2016). However, to validate this assumption it is necessary to assess the efficiency of these isolates under greenhouse and field conditions.

\section{Germination, vigor and health of soybean seeds treated with} Trichoderma spp.

In relation to the variable germination, similar behavior was observed in the tests of the effect of volatile and fixed metabolites, in which $C$. truncatum did not interfere with the seed germination process, with values above $95 \%$ germination (Tables 3 and 4). According to Mertz et al. (2009), pathogen incidence in seeds does not necessarily imply impaired 
Table 3. Effect of volatile metabolites of Trichoderma spp. on germination, germination rate index (GRI), dry matter, and incidence of Colletotrichum truncatum inoculated on soybean seeds. Means with the same letter in the column do not differ from each other by the Tukey's test at $5 \%$ probability $(p \geq 0.05)$.

\begin{tabular}{ccccc}
\hline Isolate of Trichoderma spp. & Germination (\%) & GRI & Dry matter (g) & Incidence (\%) \\
\hline UFPIT03 & $96,50 \mathrm{a}$ & $21,56 \mathrm{bc}$ & $2,71 \mathrm{ab}$ & $98,01 \mathrm{a}$ \\
UFPIT04 & $96.01 \mathrm{a}$ & $21.75 \mathrm{bc}$ & $2.82 \mathrm{ab}$ & $97.50 \mathrm{a}$ \\
UFPIT05 & $97.02 \mathrm{a}$ & $23.88 \mathrm{abc}$ & $2.72 \mathrm{ab}$ & $99.02 \mathrm{a}$ \\
UFPIT07 & $97.51 \mathrm{a}$ & $25.31 \mathrm{abc}$ & $2.68 \mathrm{ab}$ & $98.52 \mathrm{a}$ \\
UFPIT09 & $95.53 \mathrm{a}$ & $28.44 \mathrm{abc}$ & $2.72 \mathrm{ab}$ & $95.53 \mathrm{a}$ \\
UFPIT10 & $97.52 \mathrm{a}$ & $31.94 \mathrm{a}$ & $2.86 \mathrm{a}$ & $96.51 \mathrm{a}$ \\
UFPIT13 & $96.03 \mathrm{a}$ & $20.25 \mathrm{c}$ & $2.83 \mathrm{ab}$ & $97.04 \mathrm{a}$ \\
UFPIT16 & $95.04 \mathrm{a}$ & $30.00 \mathrm{ab}$ & $2.74 \mathrm{ab}$ & $94.53 \mathrm{a}$ \\
UFPIT17 & $98.51 \mathrm{a}$ & $26.94 \mathrm{abc}$ & $2.74 \mathrm{ab}$ & $98.51 \mathrm{a}$ \\
UFPIT18 & $96.03 \mathrm{a}$ & $25.88 \mathrm{abc}$ & $2.63 \mathrm{~b}$ & $99.02 \mathrm{a}$ \\
Control & $98.04 \mathrm{a}$ & $25.13 \mathrm{abc}$ & $2.82 \mathrm{ab}$ & $97.50 \mathrm{a}$ \\
\hline
\end{tabular}

Table 4. Effect of fixed metabolites of Trichoderma spp. on germination, germination rate index (GRI), dry matter, and incidence of Colletotrichum truncatum inoculated on soybean seeds. Means with the same letter in the column do not differ from each other by the Tukey's test at $5 \%$ probability $(p \geq 0.05)$.

\begin{tabular}{ccccc}
\hline Isolate of Trichoderma spp. & Germination (\%) & GRI & Dry matter (g) & Incidence (\%) \\
\hline UFPIT01 & $98.01 \mathrm{a}$ & $32.10 \mathrm{ab}$ & $2.93 \mathrm{~b}$ & $30.02 \mathrm{bcde}$ \\
UFPIT02 & $99.50 \mathrm{a}$ & $34.23 \mathrm{ab}$ & $2.91 \mathrm{~b}$ & $30.50 \mathrm{bcd}$ \\
UFPIT06 & $96.52 \mathrm{a}$ & $35.23 \mathrm{ab}$ & $2.84 \mathrm{~b}$ & $34.03 \mathrm{bc}$ \\
UFPIT08 & $100.00 \mathrm{a}$ & $34.77 \mathrm{ab}$ & $3.01 \mathrm{~b}$ & $23.04 \mathrm{cde}$ \\
UFPIT11 & $99.02 \mathrm{a}$ & $32.31 \mathrm{ab}$ & $3.23 \mathrm{a}$ & $5.52 \mathrm{~g}$ \\
UFPIT12 & $98.53 \mathrm{a}$ & $35.52 \mathrm{ab}$ & $2.89 \mathrm{~b}$ & $38.50 \mathrm{bc}$ \\
UFPIT14 & $99.41 \mathrm{a}$ & $33.41 \mathrm{ab}$ & $2.81 \mathrm{~b}$ & $17.02 \mathrm{defg}$ \\
UFPIT15 & $98.04 \mathrm{a}$ & $34.04 \mathrm{ab}$ & $2.81 \mathrm{~b}$ & $16.04 \mathrm{efg}$ \\
UFPIT19 & $97.52 \mathrm{a}$ & $27.50 \mathrm{~b}$ & $3.22 \mathrm{a}$ & $11.53 \mathrm{fg}$ \\
Quality & $99.53 \mathrm{a}$ & $35.04 \mathrm{ab}$ & $2.97 \mathrm{~b}$ & $21.02 \mathrm{cde}$ \\
Control & $99.52 \mathrm{a}$ & $38.98 \mathrm{a}$ & $2.96 \mathrm{~b}$ & $52.51 \mathrm{a}$ \\
\hline Coefficient of variation (\%) & 11.18 & 15.27 & 4.62 & 33.48 \\
\hline
\end{tabular}

germination. The presence of pathogen may be limited to the integument, which will be left in the substrate during the emergence process, without health damage to the originated seedlings.

The treatment with the isolate UFPIT10 presented the highest mean (31.94) for the action of volatile metabolites on GRI, differing only from the isolates UFPIT03, UFPITO4 and UFPIT13 (Table 3). On the other hand, the control had the highest GRI mean (38.98) for the effect of fixed metabolites, however differed only from treatment with the isolate UFPIT19 (Table 4). In addition, at the end of the third day, seeds of all treatments had already reached the maximum germination. The highest GRI value of control seeds was provided on the first day, presenting a percentage of germination of $73 \%$ whereas the other treatments presented a mean of $52 \%$. Machado et al. (2001) worked with the pathosystem Phomopsis sojaesoybean seeds and verified a higher germination rate of seeds in soil tests when compared with those in paper roll. The authors proposed that this fact is due to the mechanism of escape in which the seedling, when emerging, releases the infected integument. Thus, it may explain the result observed in the present study, in which seeds of the control treatment presented a higher GRI. When seeds are conditioned to a biotic stress, such as the incidence of a pathogen, defense mechanisms such as those responsible for the germinative process are released by them in an attempt to release the integument infected with the pathogen.

The variable dry matter, under the action of volatile metabolites, showed no effect of treatments. Similar behavior was observed for the percentage of incidence of c. truncatum in the seeds, in which the treatments did not differ from the control. The production of volatile metabolites by Trichoderma spp. depends on several factors, such as nutrient content, temperature, and humidity (Lee et al., 2016). The concentration and time of exposure to volatile compounds produced by fungi also play a critical role in measuring beneficial or inhibitory effects (Lee, 2015). During the experiment, the isolates of Trichoderma spp. remained at an average air temperature of $25^{\circ} \mathrm{C}$ and relative humidity of $55 \%$, exposed to the seeds for eight days.

However, in the action of fixed metabolites for dry matter, the isolates UFPIT11 and UFPIT19 had the highest means, with values of 3.23 and $3.22 \mathrm{~g}$, respectively, differing from the other treatments and providing a higher seed vigor. Regarding the percentage of $C$. truncatum in the seeds, the control had the highest mean (52.51\%). The lowest values were verified in treatments with the isolate UFPIT11 (5.52\%), followed by the isolate UFPIT19 (11.53\%). These isolates presented the best 
results when compared to the others and to the commercial product Quality ${ }^{\circledast}$. The high efficiency of the action of fixed metabolites of Trichoderma spp. in reducing of pathogen incidence, in which higher or similar results were observed when compared to the commercial product, indicates that the isolates present a high potential of use in the biological control. The results for the variables dry matter and pathogen incidence are in accordance with several studies, in which Trichoderma spp., in focus for Trichoderma koningiopsis Samuels, Suárez \& Evans and Trichoderma longibrachiatum Rifai, acts in reducing pathogen incidence, besides acting to promote plant growth (Haddad et al., 2017; Milanesi et al., 2013; Zhang et al., 2015).

\section{Conclusions}

All isolates of Trichoderma spp. had an antagonistic potential to Colletotrichum truncatum, either under in vitro or in vivo conditions. In the in vivo experiment, the tests with fixed metabolites showed more significant results, mainly the isolates UFPIT11 (Trichoderma sp. T5) and UFPIT19 (T. koningiopsis). Therefore, there is a need for further tests to assess the effect of fixed metabolites of all isolates of Trichoderma spp. Thus, the potential of Trichoderma species originating from native forest fragments in the biological control of phytopathogens commonly found in the region is evident. The use of these species in commercial formulations designed to control plant diseases is promising, making it necessary to assess their efficiency under greenhouse and field conditions.

\section{Literature Cited}

Agrawal, S.C.; Khare, M.N.; Agrawal, P.S. Biological control of Sclerotium rolfsii causing collar rot of lentil. Indian Phytopathology, v.30, n.2, p.176-179, 1977.

Almassi, F.; Ghisalberti, E.L.; Narbey, M.J.; Sivasithamparam, K. New antibiotics from strains of Trichoderma harzianum. Journal of Natural Products, v.54, n.2, p.396-402, 1991. https://doi. org/10.1021/np50074a008.

Baldoni, R.N. Vegetação de cerrado e conservação: relações entre teorias, influência da escala e variação espacial. São Carlos: Universidade Federal de São Carlos, 2014. 123p. Tese Doutorado. https://repositorio.ufscar.br/handle/ufscar/7381. 02 Aug. 2019.

Barratt, B.I.P.; Moran, V.C.; Bigler, F.; Van Lenteren, J.C. The status of biological control and recommendations for improving uptake for the future. BioControl, v.63, n.1, p.155-167, 2018. https://doi. org/10.1007/s10526-017-9831-y.

Begum, M.M.; Sariah, M.; Puteh, A.B.; Zainal Abidin, M.A. Pathogenicity of Colletotrichum truncatum and its influence on soybean seed quality. International Journal of Agriculture and Biology, v.10, n.4, p.393-398, 2008. https://doi.org/10.17957/ IJAB/15.1226.

Bhardwaj, N.R.; Kumar, J. Characterization of volatile secondary metabolites from Trichoderma asperellum. Journal of Applied and Natural Science, v.9, n.2, p.954-959, 2017. https://doi. org/10.31018/jans.v9i2.1303.
Botrel, R.T.; Brito, D.R.S.; Sousa, W.C.; Souza, A.M.; Holanda, A.C. Fenologia de uma espécie arbórea em ecótono Caatinga/Cerrado no Sul do Piauí. Revista Verde, v.10, n.3, p.7-12, 2015. https://doi. org/10.18378/rvads.v10i3.3587.

Claydon, N.; Allan, M.; Hanson, J.R.; Avent, A.G. Antifungal alkyl pyrones of Trichoderma harzianum. Transactions of the British Mycological Society, v.88, n.4, p.503-513, 1987. https://doi. org/10.1016/S0007-1536(87)80034-7.

Costa, A.M. Prospecção gênica e bioinformática. In: Faleiro, F.G.; Andrade, S.R.M.; Reis Junior, F.B. (Eds.). Biotecnologia: estado da arte e aplicações na agropecuária. Planaltina-DF: Embrapa Cerrados, 2011. v.1, p. 121-141.

Dennis, C.; Webster, J. Antagonistic properties of species-groups of Trichoderma. II. Production of volatile antibiotics. Transactions of the British Mycological Society, v.57, n.1, p.41-48, 1971. https:// doi.org/10.1016/S0007-1536(71)80078-5.

Ditomaso, J.M.; Van Steenwyk, R.A.; Nowierski, R.M.; Meyerson, L.A.; Doering, O.C.; Lane, E.; Cowan, P.E.; Zimmerman, K.; Pitcairn, M.J.; Dionigi, C.P. Addressing the needs for improving classical biological control programs in the USA. Biological Control, v.106, p.35-39, 2017. https://doi.org/10.1016/j. biocontrol.2016.12.005.

Ferreira, D.F. Sisvar. Versão 5.6. Lavras: UFLA/DEX. http://www.dex. ufla.br/ danielff/programas/sisvar.html. 21 Jan. 2019.

Galli, J.A.; Panizzi, R.C.; Fessel, S.A.; Simoni, F.; Fumikoito, M. Efeito de Colletotrichum dematium var. truncata e Cercospora kikuchii na germinação de sementes de soja. Revista Brasileira de Sementes, v.27, n.2, p.182-187, 2005. http://dx.doi.org/10.1590/S010131222005000200026 .

Ghisalberti, E.L.; Narbey, M.J.; Dewan, M.M.; Sivasithamparam, K. Variability among strains of Trichoderma harzianum in their ability to reduce take-all and to produce pyrones. Plant and Soil, v.121, n.2, p.287-291, 1990. https://doi.org/10.1007/BF00012323.

Grigoletti Junior, A.; Santos, A.F.; Auer, C.G. Perspectivas do uso do controle biológico contra doenças florestais. Floresta, v.30, n.2, p.155-165, 2000. https://doi.org/10.5380/rf.v30i12.2362.

Guimarães, G.R.; Ferreira, D.S.; Galvão, C.S.; Mello, S.C.M.; Carvalho, D.D.C. Ação de metabólitos voláteis e não voláteis de Trichoderma harzianum sobre o crescimento de Cladosporium herbarum. Pesquisa Agropecuária Pernambucana, v.21, n.1, p.7-11, 2016. https://doi.org/10.12661/pap.2016.002.

Haddad, P.E.; Leite, L.G.; Lucon, C.M.M.; Harakava, R. Selection of Trichoderma spp. strains for the control of Sclerotinia sclerotiorum in soybean. Pesquisa Agropecuária Brasileira, v.52, n.12, p.1140-1148, 2017. https://doi.org/10.1590/s0100$204 \times 2017001200002$.

Hlimi, S.; Rebuffat, S.; Goulard, C.; Duchamp, S.; Bodo, B. Trichorzins HA and MA, antibiotic peptides from Trichoderma harzianum. II. Sequence Determination. The Journal of Antibiotics, v.48, n.11, p.1254-1261, 1995. https://doi.org/10.7164/antibiotics.48.1254.

Isaias, C.O.; Martins, I.; Silva, J.B.T.; Silva, J.P.; Mello, S.C.M. Ação antagônica e de metabólitos bioativos de Trichoderma spp. contra os patógenos Sclerotium rolfsii e Verticillium dahliae. Summa Phytopathologica, v.40, n.1, p.34-41, 2014. https://doi. org/10.1590/s0100-54052014000100005. 
Lee, S.Y.J. Analysis of volatile organic compounds emitted by filamentous fungi and volatile-mediated plant growth. New Brunswick: The State University of New Jersey, 2015. 206p. Dissertation. https://doi.org/doi:10.7282/T30V8FSF.

Lee, S.Y.J.; Hung, R.; Yap, M.; Bennett, J.W. Age matters: the effects of volatile organic compounds emitted by Trichoderma atroviride on plant growth. Archives of Microbiology, v.197, n.5, p.723-727, 2015. https://doi.org/10.1007/s00203-015-1104-5.

Lee, S.Y.J.; Yap, M.; Behringer, G.; Hung, R.; Bennett, J.W. Volatile organic compounds emitted by Trichoderma species mediate plant growth. Fungal Biology and Biotechnology, v.3, n.7, p.1-14, 2016. https://doi.org/10.1186/s40694-016-0025-7.

Machado, J.C.; Oliveira, J.A.; Vieira, M.G.G.C.; Alves, M.C. Inoculação artificial de sementes de soja por fungos, utilizando solução de manitol. Revista Brasileira de Sementes, v.23, n.2, p.95-101, 2001. https://doi.org/10.17801/0101-3122/rbs.v23n2p95-101.

Maguire, J.D. Speed of germination-aid in selection and evaluation for seedling emergence and vigor. Crop Science, v.2, n.2, p.176177, 1962. https://doi.org/10.2135/cropsci1962.0011183X0002 00020033x.

Manandhar, J.B.; Hartman, G.L. Anthracnose. In: Hartman, G.L.; Sinclair, J.B.; Rupe, J.C. (Eds.). Compendium of soybean diseases. Saint Paul: APS Press, 1999. p. 13-14.

Mertz, L.M.; Henning, F.A.; Zimmer, P.D. Bioprotetores e fungicidas químicos no tratamento de sementes de soja. Ciência Rural, v.39, n.1, p.13-18, 2009. http://dx.doi.org/10.1590/S010384782009000100003.

Michel, B.E.; Radcliffe, D. A computer program relating solute potential to solution composition for five solutes. Agronomy Journal, v.87, n.1, p.26-130, 1995. https://doi.org/10.2134/agro nj1995.00021962008700010022x.
Milanesi, P.M.; Blume, E.; Antonioli, Z.I.; Muniz, M.F.B.; Santos, R.F.; Finger, G.; Durigon, M.R. Biocontrole de Fusarium spp. com Trichoderma spp. e promoção de crescimento em plântulas de soja. Revista de Ciências Agrárias, v.36, n.3, p.347356, 2013. http://www.scielo.mec.pt/scielo.php?script=sci_ arttext\&pid=S0871-018X2013000300010. 10 Aug. 2019.

Monsoy. Características cultivar M8808 IPRO. http://www.monsoy. com.br/variedades_monsoy/m8808-ipro. 15 Jan. 2019.

Parra, J.R.P. Biological control in Brazil: an overview. Scientia Agricola, v.71, n.5, p.420-429, 2014. https://doi.org/10.1590/0103-90162014-0167.

Reino, J.L.; Guerrero, R.F.; Hernandez-Galan, R.; Collado, I.G. Secondary metabolites from species of the biocontrol agent Trichoderma. Phytochemistry Reviews, v.7, n.1, p.89-123, 2008. https://doi.org/10.1007/s11101-006-9032-2.

Scarselletti, R.; Faull, J.L. In Vitro activity of 6- pentyl-a-pyrone, a metabolite of Trichoderma harzianum, in the inhibition of Rhizoctonia solani and Fusarium oxysporum f. sp. lycopersici. Mycological Research, v.98, n.10, p.1207-1209, 1994. https://doi. org/10.1016/S0953-7562(09)80206-2.

Smith, H.A. Production of antimicrobials and antioxidants from filamentous fungi. Maynooth: National University of Ireland, 2014. 282p. PhD Thesis. http://mural.maynoothuniversity. ie/5802. 02 Aug. 2019.

Zhang, S.; Gan, Y.; Xu, B. Biocontrol potential of a native species of Trichoderma longibrachiatum against Meloidogyne incognita. Applied Soil Ecology, v.94, p.21-29, 2015. https://doi. org/10.1016/j.apsoil.2015.04.010. 